University of Nebraska - Lincoln

DigitalCommons@University of Nebraska - Lincoln

\title{
Psychological Ownership: Theoretical Extensions, Measurement, and Relation to Work Outcomes
}

James B. Avey

Central Washington University

Bruce Avolio

University of Washington

Craig Crossley

University of Nebraska, Lincoln, ccrossley2@unl.edu

Fred Luthans

University of Nebraska-Lincoln, fluthans1@unl.edu

Follow this and additional works at: https://digitalcommons.unl.edu/managementfacpub

Part of the Management Sciences and Quantitative Methods Commons

Avey, James B.; Avolio, Bruce; Crossley, Craig; and Luthans, Fred, "Psychological Ownership: Theoretical Extensions, Measurement, and Relation to Work Outcomes" (2009). Management Department Faculty Publications. 18.

https://digitalcommons.unl.edu/managementfacpub/18

This Article is brought to you for free and open access by the Management Department at DigitalCommons@University of Nebraska - Lincoln. It has been accepted for inclusion in Management Department Faculty Publications by an authorized administrator of DigitalCommons@University of Nebraska - Lincoln. 
Published in Journal of Organizational Behavior 30 (2009), 173-191; doi 10.1002/job.583

Copyright ( 2009 John Wiley \& Sons, Ltd. Used by permission.

http://www3.interscience.wiley.com/journal/4691/home

Accepted for publication November 10, 2008.

\title{
Psychological Ownership: Theoretical Extensions, Measurement, and Relation to Work Outcomes
}

\author{
James B. Avey, ${ }^{1}$ Bruce J. Avolio, ${ }^{2}$ Craig D. Crossley, ${ }^{3}$ and Fred Luthans ${ }^{3}$ \\ 1 Department of Management, College of Business, Central Washington University, \\ Ellensburg, Washington, U.S.A. \\ 2 Foster School of Business, University of Washington, Washington, U.S.A. \\ 3 Department of Management, University of Nebraska-Lincoln, Lincoln, Nebraska, U.S.A. \\ Correspondence - James B. Avey, Department of Management, College of Business, \\ Central Washington University, Ellensburg, WA, USA; email aveyj@cwu.edu
}

\begin{abstract}
Viewing psychological ownership as a positive resource for impacting human performance in organizations, the present study investigated the components of an expanded view of psychological ownership. Confirmatory factor analyses on a proposed measure of psychological ownership provided support for a positively-oriented, "promotion-focused" aspect of psychological ownership comprised of four dimensions: self-efficacy, accountability, sense of belongingness, and self-identity. In addition, territoriality was examined as a unique and more "prevention-focused" form of ownership. Practical implications and suggestions for future research on psychological ownership and positive organizational behavior conclude the article.
\end{abstract}

\section{Introduction}

Conventional wisdom suggests that people will take better care of, and strive to maintain and nurture the possessions they own. This "sense" of ownership, and this "motivation" to protect and improve the object of the ownership, has stimulated organizational behavior scholars to better understand the positive construct of psychological ownership. For example, recent interest has focused on what constitutes employee ownership and the outcomes it may produce (Cram \& Paton, 1993; Dirks, Cummings, \& Pierce, 1996; Pierce, Kostova, \& Dirks, 2001; Pierce, O'Driscoll, \& Coghlan, 2004; Pierce, Rubenfeld, \& Morgan, 1991; Pratt \& Dutton, 1998; Rousseau, 2003; Wagner, Parker, \& Christianson, 2003).

As noted by O'Reilly (2002, p. 19): “when managers talk about ownership, what they typically want to instill is not financial ownership but psychological ownership-a feeling on the part of the 
employees that they have a responsibility to make decisions that are in the long term interest of the company." More precisely, psychological ownership has been described as a cognitive-affective construct defined as, "the state in which individuals feel as though the target of ownership or a piece of that target is theirs," and reflects "an individual's awareness, thoughts, and beliefs regarding the target of ownership" (Pierce, Kostova, \& Dirks, 2003, p. 86).

We propose that such psychological ownership falls within the emerging literature of positive organizational behavior or POB. Psychological ownership has much in common with more widely recognized POB constructs and approaches such as psychological capital (e.g., Luthans, Youssef, \& Avolio, 2007), positive organizational scholarship (e.g., Cameron, Dutton, \& Quinn, 2003), character strengths and virtues (e.g., Peterson, 2006; Peterson \& Seligman, 2004) and psychological well-being (e.g., Quick \& Quick, 2004; Wright \& Cropanzano, 2004; Wright, 2005). In particular, not only does psychological ownership share a sense of positivity and striving for accomplishment and success with these related $\mathrm{POB}$ constructs, but psychological ownership also fits the specific POB inclusion criteria suggested by colleagues (Luthans, 2002a, 2002b; Luthans et al., 2007, i.e., based on theory, research and measurement; state-like and thus open to change and development; and having performance impact in today's organizations).

Although psychological ownership has not previously been associated with POB, we believe it can be conceptualized as a positive psychological resource (see Fredrickson, 2001; Hobfoll, 2002). Like other psychological resources, psychological ownership can be measured, invested in, developed, and managed for performance impact and competitive advantage. Even though researchers have begun to explore relationships between psychological ownership and desired outcomes such as organizational citizenship behaviors (Pierce et al., 2003), there remains a need for further theory development and empirical research. The major purpose of this study is to further define and develop a multi-dimensional measure of psychological ownership. A review of the literature on psychological ownership revealed that there were two unique and independent forms of ownership that have yet to be operationally defined. These relate to a more defensive, prevention-based ownership, and a more constructive, promotion-focused ownership.

In addressing the conditions that promote ownership, as well as how ownership relates to individual outcomes such as work attitudes and performance (Pierce et al., 2003), a secondary aim of this study was to examine how different types of leadership may create conditions for more promotion versus preventative forms of psychological ownership. In this way, the condition of leadership can be considered as a contextual factor affecting the type of psychological ownership felt and exhibited by followers.

\section{Conceptual Background}

The starting point in providing a conceptual framework for psychological ownership is to identify its targets and assumptions. Ownership (the state of being an owner and having the right of possession) is found in almost all societies. When people have a sense of ownership, they experience a connection between themselves and various tangible and intangible "targets" (Dittmar, 1992). The term "target" in the psychological ownership literature is quite broad and refers to whatever the object of attachment represents to an individual or group. These targets may be something as small as a preferred seat in the company cafeteria, or as large as the organization or industry as a whole. For example, in the workplace a target of ownership for a technician may be a preferred computer program or set of tools, an engineer may feel ownership in a particular product design, an executive may feel 
ownership in a particular organizational strategic initiative, mission or idea, and a new employee may eventually feel ownership in the entire organization. Such targets of ownership can become so deeply rooted within people's self- identity that they can become viewed as an extension of the self (Belk, 1988; Dittmar, 1992; Cram \& Paton, 1993). Indeed, Brown et al. (Brown, Lawrence, \& Robinson, 2005) argue that ownership and self-identity are so interrelated that people engage in territorial behaviors, such as marking or defending their territory as a way to identify and defend possessions as an extension of themselves.

Based on literature pertaining to what constitutes possession and ownership, Pierce et al. (2001) concluded: (1) the feeling of ownership is innately human, (2) psychological ownership can occur toward both tangible and intangible objects (targets), and (3) psychological ownership has important emotional, attitudinal and behavioral effects on those that experience ownership. These conclusions serve as a starting point for how psychological ownership was defined and its effects were used in this study.

Pierce et al. (2001) have argued that psychological ownership is discriminant from other related constructs in its conceptual core and motivational bases, namely possessiveness. Van Dyne and Pierce (2004) extend this argument by comparing psychological ownership with other constructs such as commitment and satisfaction. In particular, they emphasize that psychological ownership asks the question, "How much do I feel this organization is mine?" Whereas commitment asks, "Should I maintain my membership in this organization," and satisfaction asks, "What evaluative judgments do I make about my job?" Thus, the explicit focus on possessiveness is a primary distinguishing factor in psychological ownership.

\section{Forms of psychological ownership: promotion and prevention}

The basis for examining two unique and independent forms of psychological ownership comes from the work of Higgins' $(1997,1998)$ regulatory focus theory. He proposes that individuals have two basic self-regulation systems: promotion and prevention. Kark and Van Dijk (2007, p. 502) noted that, "individuals who operate primarily within the promotion focus are more concerned with accomplishments and aspirations ... and show more willingness to take risks," whereas" individuals who operate primarily within the prevention focus are more concerned with duties and obligations and experience emotions of anxiety and agitation." According to Higgins $(1997,1998)$, self-regulation refers to the way individuals select goals. Those who use a promotion-focused approach pursue goals that reflect their hopes and aspirations. On the other hand, those that use prevention goals focus on what to avoid for reducing punishment, sticking with rules and obligations. Kluger, Stephan, Ganzach, and Hershkovitz (2004) describe these two conflicting motivations as the motivational source in pursuing all goals.

Higgins $(1997,1998)$ argues that both prevention and promotion are needed for human survival and that one approach is not necessarily more desirable then the other. For example, in certain contexts, a promotion focus is necessary to motivate development and improvement. Whereas in other contexts, what is required is a more preventative focus where individuals seek to ensure stability, safety, and predictability. Liberman, Idson, Camacho, and Higgins (1999) have also shown that regulatory foci are connected to values of conservation (prevention) and openness to change (promotion). Those with a prevention focus were more inclined not to exchange currently or previously possessed objects versus those in a promotion focus.

When applied to examining psychological ownership, individuals who are more promotion oriented may experience feelings toward targets of ownership that are quite different from those who are prevention oriented. For example, in a scenario where sharing information may lead to change and improvement within a company, a manager possessing promotive psychological ownership with a successfully completed project may decide to share information "he owns" with a cohort or team in a different division of the company because he sees improvement in the company as personally fulfill- 
ing. In contrast, those with a more preventative focus may carefully monitor and withhold information from others because they seek to avoid change and maintain stability.

\section{The role of territoriality in psychological ownership}

Brown et al. (2005, p. 577) have noted that "Organizational members can and do become territorial over physical spaces, ideas, roles, relationships, and other potential possessions in organizations" and that to limit territoriality as being "petty, political or self-serving is to overlook their importance to employees in contemporary work organizations." When individuals form bonds of ownership over objects in the organization including physical, informational or social objects, they may seek to mark those possessions as belonging exclusively to themselves. In addition, if individuals anticipate infringement on their targets of ownership, they may engage in protective territoriality to maintain levels of ownership and to communicate ownership to potential threats and the social unit as a whole.

In developing a theoretical foundation of territoriality, Brown et al. (2005) explicitly focused on the concept of territoriality as being behavioral and propose $(2005$, p. 580) that "the stronger an individual's psychological ownership of an object, the greater the likelihood he or she will engage in territorial behaviors." However, in light of Pierce et al.'s (2001) argument that psychological ownership is a cognitive-affective construct, this study leans heavily on cognitive aspects (versus behavioral displays) of territoriality as a more preventative form of psychological ownership.

Two distinguishing factors between feelings of territoriality and the more promotion-focused dimensions of psychological ownership are: (1) the use of an external reference for territoriality and (2) defensiveness. Feelings of territoriality are heightened when individuals fear their objects of ownership may be influenced by external entities. Exhibiting a prevention-focused mode, individuals mark their territory in ways they believe external constituencies will recognize and respect. For example, preventative feelings of territoriality may cause individuals to take actions "prior to an infringement with the purpose of thwarting infringement actions taken by others" (Brown et al., 2005, p. 538). Thus, feelings of territoriality emerge as being focused on both an external (e.g., potential infringer) and/or an internal entity (the self) (Brief \& Weiss, 2002). Territoriality tends to be preventative (e.g., marking territory, using anticipatory defenses to prevent infringement, and reactionary defenses to prevent future infringements), rather than promoting the good of the work group.

Territoriality leads people to become too preoccupied with "objects of ownership," at the expense of their performance or other pro-social behaviors. Furthermore, the fear of losing one's territory and associated self and social identity may promote politicking and prohibit transparency, collaboration, and information sharing. Notwithstanding these potentially negative outcomes, it is also possible that feelings of territoriality may promote positive organizational outcomes. For example, territoriality may lead to increased performance and retention, if individuals believe by protecting their territory they are doing what's right (Altman, 1975). Also, if the individual's work is less team-based and more based on being an individual contributor, for example, a sales agent who "owns a particular territory," then a territorial orientation may lead to positive outcomes. In other words, even territorial psychological ownership with its typically negative connotation may have a positive side.

\section{Dimensions of psychological ownership}

Building on the three recognized dimensions of psychological ownership (i.e., belonging, self-efficacy, and self-identify, Pierce et al., 2001), the concepts of territoriality and accountability are posited as additional aspects of psychological ownership. Feelings of psychological ownership over a target 
draws upon the concepts of territoriality as discussed above, and also self-efficacy, accountability, belongingness and self-identity.

\section{Self-efficacy}

Self-efficacy relates to people's belief they can successfully implement action and be successful with a specific task (Bandura, 1997). White's (1959) early conceptualization of ownership and possession argued that one's feelings of ownership may be inextricably linked to the individual's need for effectance. Furby (1991) suggested that feelings of ownership emerge even in young children because of the motive to control objects and to be effectant with their application. This freedom to control one's actions is a psychological component that results in feelings of self-efficacy (Bandura, 1997) and may promote a sense of psychological ownership concerning a particular task, process, and procedure. This self-efficacy component of psychological ownership seems to say, "I need to do this task, I can do it, and I therefore own the responsibility for achieving success."

\section{Accountability}

Accountability has become a popular concept in business and public policy domains. Accountability is "the implicit or explicit expectation that one may be called on to justify one's beliefs, feelings and actions to others" (Lerner \& Tetlock, 1999, p. 255). Accountability can be considered to be a component of psychological ownership primarily through two mechanisms: (1) the expected right to hold others accountable and (2) the expectation for one's self to be held accountable.

Accountability as a source of psychological ownership is evident in many areas of society such as economic systems and sports teams. For example, the owners of major pro sports teams hold others (coaches, players) accountable for team performance, while they themselves are held accountable by other constituents (media, fans) for the team and franchise's failures and successes. Expectations of the perceived right to hold others accountable and to hold one's self-accountable are consistent with Pierce et al.'s (2003) description of expected rights and responsibilities. First, individuals who experience higher feelings of psychological ownership expect to be able to call others to account for influences on their target of ownership. The expectation of information sharing and permission to influence the direction of the target are consequences of this expected right to hold others accountable. Second, individuals not only have expected rights about holding others accountable, they have expected responsibilities for the self, sometimes described as a sense of burden sharing. When targets of ownership are seen as an extension of the self, accountability for what happens to and with those targets has implications for what happens to and with the self. This is also evident in Pierce et al.'s (2003) use of descriptive behaviors such as stewardship and self-sacrifice to characterize those with high levels of psychological ownership.

\section{Belongingness}

The human need for a home or a place to dwell has been articulated over the years by social psychologists (e.g., Ardrey, 1966; Duncan, 1981) as a fundamental need that exceeds mere physical concerns and satisfies the pressing psychological need to belong. For example, Ardrey (1966) argued people will take ownership of, and structure their lives around, possessions in an effort to satisfy their need for belonging. This example is highlighted by Mehta and Belk (1991) who note that immigrants tend to retain possessions as "security blankets" to provide them with a sense of place or belongingness. Feelings of psychological ownership through attachment to a place or an object, becomes a "home" or place for the individual (Pierce et al., 2001).

Beyond belongingness being enhanced by physical possessions, belongingness in terms of psychological ownership in organizations may best be understood as a feeling that one belongs in the organization. When people feel like owners in an organization, their need for belongingness is met by 
"having a place" in terms of their social and socio-emotional needs being met. The need to belong in a work place may be satisfied by a particular job, work team, work unit, division, organization or industry as a whole.

Self-identity

Self-identity along with social identity are recognized as major parts comprising the self-concept domain. Researchers have noted that groups of people (Abrams \& Hogg, 2004) and possessions often act as symbols through which people identify themselves (Belk, 1988; Rousseau, 1998). Specifically, it has been noted that individuals establish, maintain, reproduce and transform their self-identity through interactions with tangible possessions (Dittmar, 1992) and intangibles such as an organization, mission or purpose (Rousseau, 1998). For example, people may define themselves as a sports car driver, a yacht owner, or an antique collector. These targets of ownership are often used as descriptors of one's identity. Feelings of psychological ownership over these objects may provide a foundation from which individuals can identify themselves as being unique, thus contributing to their personal identity.

In addition to targets such as objects, a job, or a work team, individuals may identify with an organization, mission or purpose (Rousseau, 1998). This is because people have a strong drive to identify with the settings in which they work (Ashforth \& Mael, 1989). According to Tajfel's social identification theory, humans are not only calculative by nature, but also expressive of feelings and values (Tajfel \& Turner, 1986). As stated by Shamir, House, and Arthur (1993, p. 580) "We 'do' things because of what we 'are', because by doing them we establish and affirm an identity for ourselves." Albert, Ashforth, and Dutton (2000) suggest that by internalizing the organizational identity as a definition of the self, the individual gains a sense of meaningfulness and connectedness. Thus, individuals may feel a sense of psychological ownership over a target at multiple levels to the extent that it appeals to and affirms their values and self-identity. Since people are expressive and seek opportunities to affirm their self-identity, the need for self-identity can be considered a potential component of psychological ownership.

Self-identity is related yet distinct from having a sense of belongingness. For example, individuals can feel a sense of belongingness in a place or with a group and not necessarily identify with that place or group. For example, auto workers may experience feelings of belongingness or a "second home" when they stand at their station on the assembly line. However, this does not mean they identify with the organization. Contrarily, a newly hired employee at an organization such as United Way may strongly self- identify with the mission of the organization. However, it is unlikely the employee would feel "at home" and belongingness as a new hire in the organization. Thus, although the underlying principle of ownership may be manifest in both belongingness and self-identity, they remain distinct, yet still related, constructs.

In sum, as people develop, they learn what is and is not part of the self. When specific targets become classified as an extension of the self, they become central to one's self-identity such that individuals define themselves by these targets (Belk, 1988). In addition, these targets provide a means of demonstrating self-efficacy and a means for holding themselves and others accountable for decisions. Finally, the need for belongingness may be satiated by targets of psychological ownership such that an individual feels motivated to possess a "home" wherein targets of ownership may be assimilated. Thus, promotion-oriented psychological ownership is a multi-dimensional construct composed of the following four content domains: self-efficacy, accountability, sense of belonging, and self-identity.

\section{Social exchange and self-identity}

One point of departure in examining two unique and independent forms of psychological ownership can be found in the social exchange and self-identity literatures. Specifically, relationships be- 
tween employees and organizations that are characterized by transformations in self-identity are more optimal than relationships characterized by exchange (Blau, 1964).

When employees feel ownership in an organization, they tend to engage in positive behaviors driven by the sense of responsibility accompanying feelings of ownership. The transactional exchange between employees and their organization is such that the organization satisfies the needs of participants, who in turn reciprocate by developing feelings of ownership and a corresponding sense of responsibility. Exchange theory (Blau, 1964) asserts that people maximize gain through a series of such exchanges.

Katz and Kahn (1978) argue personal identification is a major source of internal motivation that moves beyond the transactional exchange of pay for performance. They define value expression of self- identification as "expressing in words and acts one's important values and this identifying one's self and maintaining a satisfying self-concept" (Katz \& Kahn, 1978, p. 361). When personal identification is integrated with an organizational target, feelings of ownership in that target may drive desirable behavior not prescribed by specific roles. This behavior can be considered in terms of expressing one's self-identity through the target of ownership.

Additional support for identification-based ownership being influential in terms of sustainability and desirable outcomes beyond exchange based levels of ownership comes from the charismatic and transformational leadership literature. Shamir et al. (1993) argue that individuals come to identify with a leader to the extent their values become aligned with the leader. As a result, Bass and Riggio (2006) argue that individuals will disregard personal gain to apply effort toward the leader's vision. This is a process of expressing one's self-identity that transcends the typical exchange based leadership known as transactional, which would be more associated with accountability and territoriality (Dittmar, 1992). The individual's frame of reference moves from an exchange question, "what will I gain from this effort," to the self-identity statement "this effort is an expression of who I am."

In conclusion, in this study several attitudinal and behavioral outcomes of psychological ownership were explored to better understand the semantic network of psychological ownership. The underlying rationale for such linkages is best understood in terms of both exchange (effort applied due to the satisfying of needs by a particular organizational target) and self-identity (effort applied from using the target of ownership as an expression of personal identity) theories as complementary conceptual frameworks.

\section{Methods}

The primary sample for this study was comprised of a heterogeneous sample of 316 working adults in the United States from a wide cross section of organizations who volunteered to participate in a large Midwestern University sponsored research project on leadership and motivation. This target sample received an e-mail requesting participation in a short web-based survey. Of those that received the e-mail, 316 individuals (87 per cent response rate) participated and completed all of the survey measures described below. Of those participants, 37 per cent identified themselves as entry level, 42.7 per cent were mid-level including supervisors, and 18.7 per cent of participants were at a senior level manager or higher position. The mean age for the sample was 32.1 years (s.d. 13.7) with 7.1 years (s.d. 8.6) tenure at the existing organization. There were 46.5 per cent females, 49.7 per cent males and 3.8 per cent of the participants did not list gender. The sample was 88 per cent white and 3 per cent Asian, 2 per cent Black, 1 per cent Hispanic, and 6 per cent not listing ethnicity. Of the participants, 27 per cent indicated they worked virtually from their manager (e.g., their manager was not in their im- 
mediate location) for more than 50 per cent of their working hours. In terms of education, 51 per cent of participants reported at least some college or vocational training, 33 per cent earning a bachelor's degree, 9 per cent earning a master's degree and 1 per cent earning a PhD or equivalent.

\section{Psychological ownership measure}

Based on the theoretical framework presented above, a new measure of psychological ownership was developed. Both deductive and inductive processes were used for item generation (Hinkin, 1995, 1998). Item generation was initiated with the following steps: (1) a comprehensive review of the literature on psychological ownership, possessiveness, and related terms, and (2) discussions with an organization behavior research group consisting of faculty and doctoral students. From the review of literature and group discussions, the four theory-driven domains determined to best constitute the dimensions of promotion-oriented psychological ownership included self-efficacy, accountability, sense of belonging, and self-identity with the target. The domain of territoriality was identified as a dimension of a preventative form of ownership.

In the next step, the group generated 55 items representing the five theory-driven components of psychological ownership. Four of these items were taken from existing scales of self-efficacy (Parker, 1998) and organizational identity (Mael \& Ashforth, 1992). A group of research associates (six organizational behavior doctoral students), blind to the aims of this particular study, served as coders to sort items into a priori categories to determine which items best reflected each of the five dimensions of ownership. Items were provided to these coders in a randomly sorted list. Individual items that were accurately assigned to their respective category by at least 80 per cent of the coders were retained for further analyses (see MacKenzie, Podsakoff, \& Fetter, 1991 for review of this approach). From these 55 items, 33 were identified as best capturing the proposed content domains and thus where selected for further refinement.

We followed the guidelines of Stanton, Sinar, Balzer, and Smith (2002) for item reduction. Specifically, item reduction is often done on the basis of maximizing internal consistency, which may lead to overly narrow operationalizations of constructs. Accordingly, Stanton et al.'s (2002) recommended also examining external relationships with theoretically linked constructs in an effort to retain items that assess the full construct.

Accordingly, the scale's internal consistency (Cronbach's alpha) was maintained by selecting items based on reliability with each item removed, and the corrected item-total correlations. Next, to maintain construct breadth, the bivariate relationship between each item and the summated measure of respective third variables were examined. Additionally, the scale scores for third variables were regressed on the subscale items to determine which items emerged as the strongest predictors of the outcomes. Finally, the subscale items were reviewed to validate the extent to which each was redundant with others. Items that were less duplicative, stronger predictors of the outcome variables and maintained adequate internal reliability were proposed to: (1) capture the breadth of the construct, (2) enhance internal reliability, and (3) assure predictive validity. These items were included in the final measure of psychological ownership.

Using each of these criteria, the 33 items used in the study were reduced to 16 items ( 3 items for each of the 4 components) for the promotion-oriented ownership scales and 4 items for the feelings of territoriality. Internal reliabilities for the components were: self-efficacy $(\alpha=.90)$, accountability $(\alpha=.81)$, sense of belongingness $(\alpha=.92)$, and self-identity $(\alpha=.73)$. The four territoriality items also demonstrated acceptable reliability $(\alpha=.84)$. Finally, to assure that items captured the breadth of the content domain as well as face validity, the 16 selected items were sent to the previously mentioned group of faculty and doctoral students for review. These reviewers agreed that each of the items selected were 
either the best choices or among the best choices in terms of capturing the breadth of the construct as well as having high face validity. The final 16 items of the psychological ownership measure can be obtained free of charge at www.mindgarden.com for use in research, with two example items of each scale presented in Appendix A. Responses were made on a 6 point Likert-type scale ranging from $1=$ strongly disagree to $6=$ strongly agree.

We subjected this 16-item psychological ownership measure to a CFA and to competing model comparisons using Mplus. Maximum likelihood estimation techniques were used to determine item loadings on respective facets. Next, each of the four components was specified to load on the second order factor representing the general theory-driven construct of psychological ownership. This model yielded a CFI of 0.96 , RMSEA of 0.07 and a SRMR of 0.06 . All items significantly loaded on their respective components greater than $0.60(p<.01)$ and 29 out of the 32 observed items loaded on their respective factor at $0.70(p<.01)$ and higher (see Appendix A).

Next, a series of model comparisons were conducted to ensure the proposed factor structure not only fit by traditional standards, but also represented a better fit to the data than alternative models of the factor structure. To ensure the discriminant validity of the various facets of psychological ownership, the model comparisons included merging related facets onto the same latent construct. For example, items of self-identity and sense of belongingness were specified to load on a single latent construct. This model was then subjected to a Chi-square difference test of model fit to determine the best fitting model. This process was repeated for several iterations of merged components. Next, a Chisquare test of significance was conducted to ensure that the model was best represented as a second order model rather than a first order model where all items would load directly on to the psychological ownership latent factor.

Law, Wong, and Mobley (1998) present a framework for second order multi-dimensional constructs where the second order factor represents the common variance between components. While this concept has been defended qualitatively, a model comparison of the first order versus second order factors offers support to these conceptual arguments. As evident in Table 1, the second order factor model emerged as significantly better than the first order factor model as well as all potential combinations of components as evidenced by the highest fit indices and lowest error indices of all competing models. Thus, psychological ownership is best represented by the second order measurement model proposed in this study.

To determine confirmatory factor analytic fit for the feelings of territoriality scale, each item was loaded on to a single order latent factor of territoriality. The instrument demonstrated very strong fit with the data $(\mathrm{CFI}=1.00$, RMSEA $=0.01, \mathrm{SRMR}=0.01)$ and all items loaded at 0.7 or greater. These findings suggest that this form of psychological ownership represented a distinct aspect in line with its more preventative focus.

A second sample was also used to replicate and verify the instrument's psychometric properties and factor structure. This sample was comprised of 283 full-time employees of a metallic plating manufacturing organization. Employees operated heavy machinery to dye, polish and plate metallic parts for auto and motorcycle manufacturers. Daily responsibilities included handling toxic chemicals and working indoors with varying temperatures within the building. Ages for this sample ranged from 19 to 60 with a mean age of 38.6 years and approximately 22 per cent of participants were female. All participation was voluntary and there was no reward or penalty for not participating. Survey instruments were used for research purposes only.

Individuals completed the 16-item psychological ownership scale along with other scales not reported here. Similar to the primary study, results indicated acceptable reliabilities for feelings of territoriality $(\alpha=.83)$, as well as each component of promotion-oriented psychological ownership including self-efficacy $(\alpha=.89)$, accountability $(\alpha=.86)$, sense of belongingness $(\alpha=.92)$ and self- identity $(\alpha$ $=.80)$ and the overall promotion-oriented psychological ownership measure $(\alpha=.91)$. This follow-up 


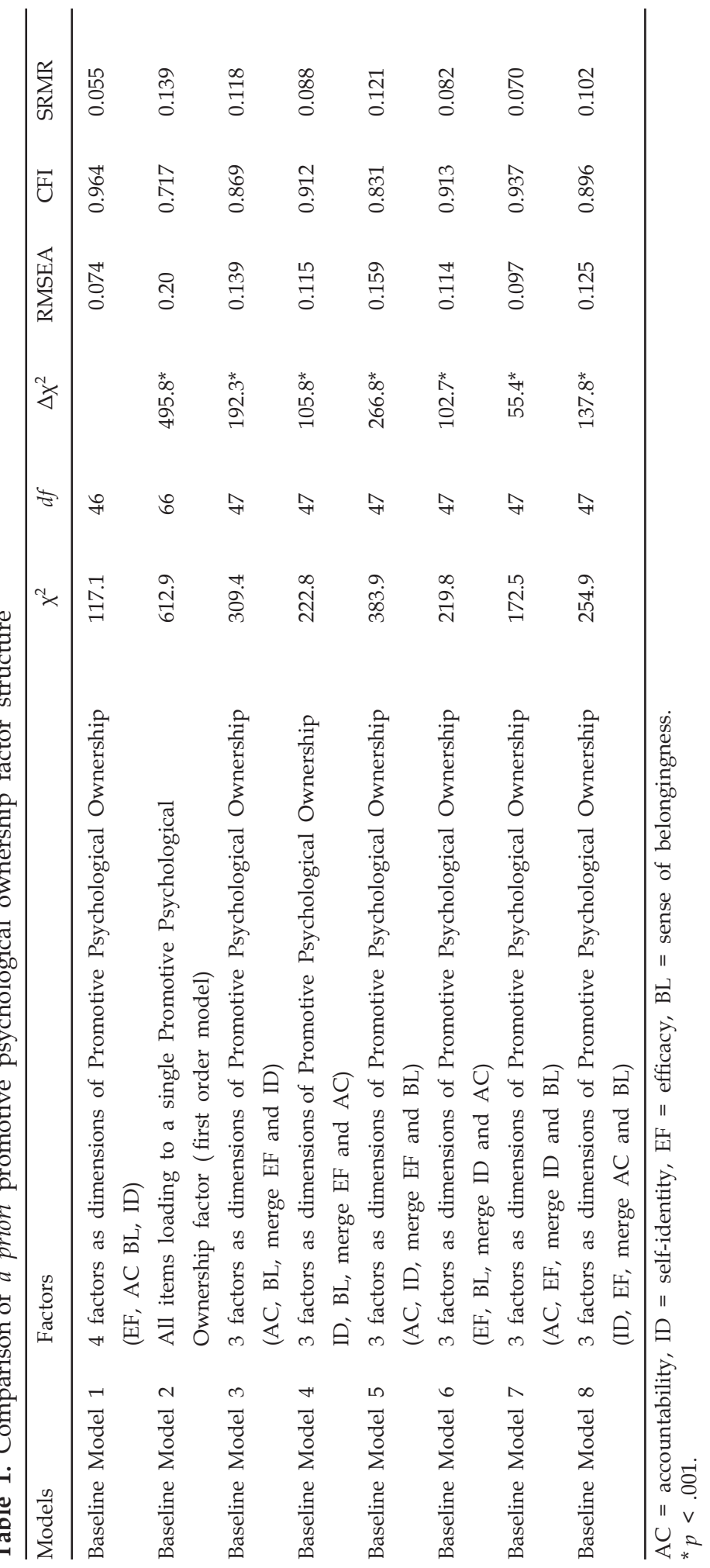


study also provided further support for the second order factor structure. Specifically, fit indices of $\mathrm{CFI}=0.97$, the RMSEA of 0.06 , the SRMR of 0.05 were all within acceptable ranges suggesting strong fit for the second order model. Individual item loadings are indicated in Appendix A. The CFA for the single order factor of territoriality indicated by the four items also had an excellent fit CFI of 0.98, RMSEA of 0.04 and the SRMR of 0.02. Item loadings for the main study and this follow- up study can be seen in Appendix A.

\section{Additional study measures}

Beyond demonstrating and validating confirmatory factor analytic fit as well as providing conceptual distinctiveness, when validating any new survey instrument such as used in this study, it is also important to show the nomological network including both antecedents and outcomes of the variable of interest (Judge, Erez, Bono, \& Thoresen, 2003). Thus, several other variables were included in the primary study to explore the corresponding semantic network.

Transformational leadership

To assess transformational leadership the 20-item Multi-factor Leadership Questionnaire (MLQ) version 5X (Avolio, Bass, \& Jung, 1999) was used. Since these dimensions are all positively correlated, each dimension was treated as an indicator of a higher order factor. Individuals were asked how often their immediate supervisor engaged in a list of behaviors on a scale from 0 to 4 (not at all, to frequently, if not always). The MLQ version 5X yielded an acceptable reliability alpha $(\alpha=.96)$.

\section{Organizational citizenship behavior}

OCBs were assessed by a 16-item instrument developed by Lee and Allen (2002), which has 8 items for individual oriented OCBs (e.g., "I help others who have been absent") and 8 items for organizational oriented OCBs (e.g., "I offer ideas to improve functioning of the organization"). Responses were made on a 6 point Likert type scale ranging from $1=$ strongly disagree to $6=$ strongly agree. Internal reliability was 0.89 for the individual OCBs and 0.90 for the organizational OCBs.

\section{Organizational commitment}

This was measured using four items from Allen and Meyer's (1990) affective organizational commitment scale. Items were selected by the same faculty and doctoral student group mentioned above based on face and content validity. The affective commitment scale has been used separately in prior research given its focus on the employee's desire to remain with the organization versus a calculation of costs and benefits of leaving. A sample item from the affective commitment scale is: "I would be happy to spend the rest of my career with this organization." This scale demonstrated internal reliability of 0.89 .

\section{Workplace deviance}

This was measured using 10 items from Fox and Spector's (1999) counterproductive work behaviors scale. Internal reliability for this scale in the present study was 0.77. Example items are "purposely ignored your boss" and "failed to help a co-worker." Ratings were on a 1-6 scale of "Hardly ever, if ever" to "Frequently, if not always." The same research group chose 10 items from this instrument to reduce scale length. The chosen items represented five items from the minor personal and five items from the minor organizational dimensions of the counterproductive work behaviors instrument. The specific items selected from each dimension were the 5 with the highest reported frequency in previous research (Fox \& Spector, 1999). Aside from being the most common forms of deviance, 
items with the highest frequency were selected to maximize variance and to better understand the nature of the relationship with psychological ownership.

Intentions to stay

This measure used Bluedorn's (1982) staying-leaving index. The SLI uses four items rating the chances the individual believes they will remain employed with the organization 3 months, 6 months and 12 months and 2 years from "now" on a scale from terrible to excellent. Internal reliability for this scale was 0.93 .

Job satisfaction

This used three items from Hackman and Oldham's (1980) Job Diagnostic Survey previously used by Judge and Bono (2001). A sample item from this instrument is "Generally speaking, I am satisfied with my job" $(\alpha=90)$.

\section{Results}

Correlation results for all study variables are reported in Table 2. To provide evidence of convergent validity, the relationships between measures of psychological ownership and other conceptually related constructs, such as transformational leadership were examined. Contrary to the more promotion form of ownership, feelings of territoriality showed no relationship with outcome variables or transformational leadership. As expected, transformational leadership was positively related to psychological ownership $(r=.23, p<.01)$. Psychological ownership was positively related to ratings of individual OCBs $(r=.15, p<.01)$ as well as organization-targeted OCBs $(r=.57, p<.01)$, with the latter finding supporting that the organization would potentially be a more important target of psychological ownership. Affective commitment toward the organization was also positively related to psychological ownership with an $r=.48(p<.01)$. As anticipated, workplace deviance was negatively related to psychological ownership $(r=-.36, p<.01)$ and intentions to stay with the organization were positively related to psychological ownership $(r=.50, p<.01)$. Finally, job satisfaction was positively related to psychological ownership $(r=.49, p<.01)$.

In sum, the purpose of this study was to examine initial psychometric properties of the psychological ownership measure including promotion and preventative forms of ownership. Results suggest that promotion-oriented psychological ownership may be conceptualized and reliably measured as a second order factor comprised of self-efficacy, accountability, belongingness, and selfidentity. Constructs in the nomological network include affective commitment, OCBs, satisfaction, workplace deviance, intentions to stay with the organization, and transformational leadership. Results also suggest discriminant validity between promotion-oriented and preventative psychological ownership.

\section{Discussion}

We set out to develop a theory-driven multi-dimensional measure of psychological ownership that included the full breadth of the construct including more promotion-focused aspects such as belongingness, as well as a prevention focus such as territoriality. The primary study also examined the corre- 


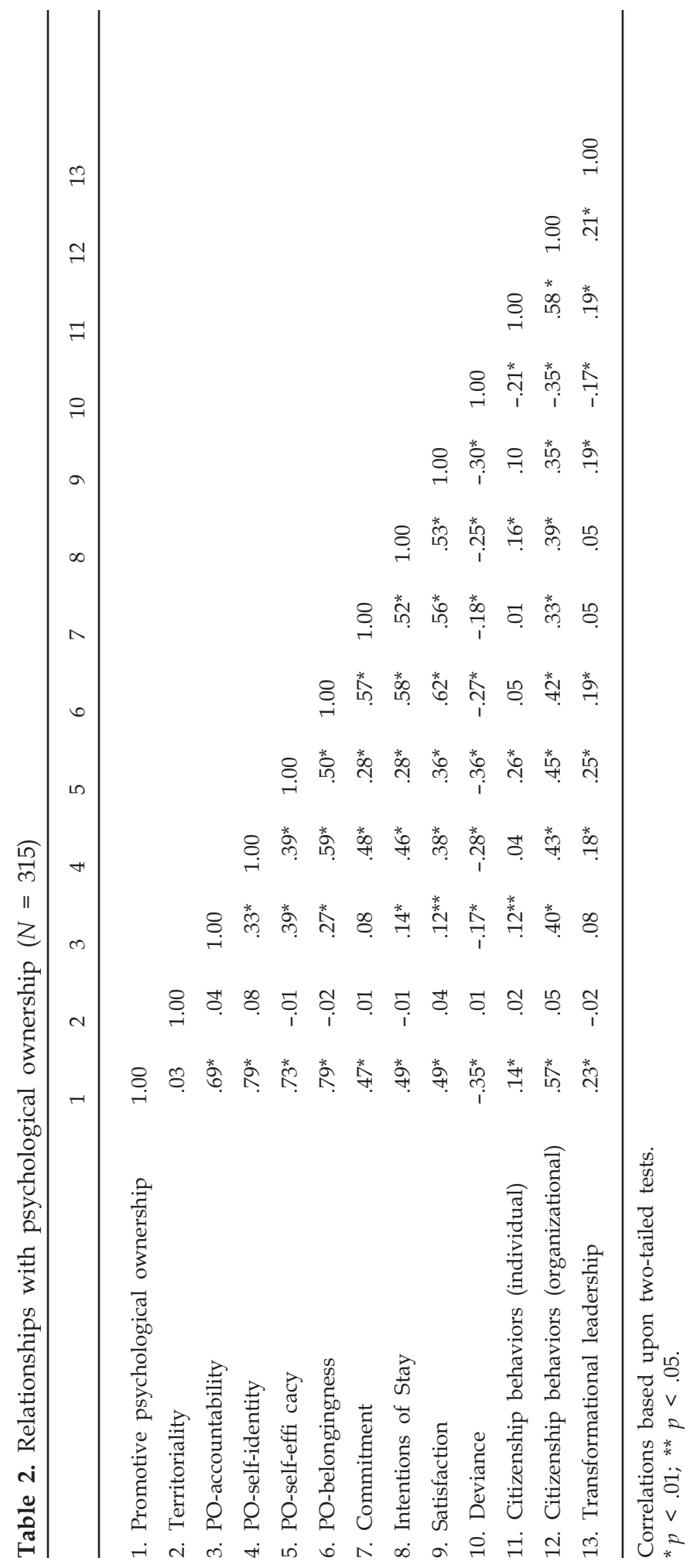


sponding nomological network of antecedents and outcomes. The rationale and foundation for examining this multi-dimensional construct from the perspective of a promotion and prevention motivational perspective was supported by Higgins' $(1997,1998)$ regulatory focus theory of motivation. This basic motivational framework was used as a point of departure for examining the composition of what may potentially be a core positively oriented characteristic of human behavior called psychological ownership.

The results from this empirical investigation may have significant implications for how positive organizational behavior conceives psychological ownership. Specifically, the extent to which one feels like an owner over a target will be reflected in whether the individual personally identifies with the target, feels a sense of belongingness toward the target, considers it a right to hold oneself and others accountable for their influence on the target, and the extent to which that target satisfies the need for efficacy. The results hopefully suggest that these four factors may represent what constitutes a theoretically broadened and enriched understanding of psychological ownership.

In addition to validating psychometric scale properties, exploratory study results suggest significant relationships between promotive psychological ownership and several important individual level outcomes in organizations. These preliminary relationships provide strong support that future research on psychological ownership is likely to unveil important links in positive organizational behavior research. Specifically, psychological ownership was positively related to transformational leadership which suggests that transformational leaders may be able to create conditions to enhance psychological ownership. This finding will hopefully stimulate future research addressing the conditions in organizations, work groups and individuals that enhance psychological ownership. In particular, transformational leadership may be an important contextual factor that contributes to employee psychological ownership.

Another area of future research could involve the unpacking of the relationship between psychological ownership and other workplace attitudes. For example, the results from this exploratory study found strong, positive relationships between promotion-oriented psychological ownership and employee commitment, job satisfaction and intentions to stay with the organization, each of which may be desirable employee attitudes to develop in today's organizations. In addition, both types of organizational citizenship behaviors (individual and organizational) as well as workplace deviance (negative relationship) were related to promotive psychological ownership.

Although these conclusions are still preliminary, as construct validation is a continual process that cannot be accomplished in a single study, findings did suggest that the more promotion-focused aspects of ownership may have more favorable outcomes for organizations, while the more preventionfocused territoriality may not be as desirable in certain circumstances. In any case, these initial research findings should stimulate more thinking and future theory-building, research, and application on the positive concept of psychological ownership.

\section{Strengths and limitations}

Our methods of data collection and analyses provided both strengths and potential limitations for interpreting the study results. Analytical techniques to validate the psychometric properties of the psychological ownership measure were generally strengths of this study. For example, the confirmatory factor analytic model comparisons demonstrate support for the four factor structure beyond simply acceptable fit and error indices as the four factor model emerged as superior in each model comparison including a single order factor structure.

Despite the strengths, there are several limitations that need to be recognized. First, formal hypotheses and a theoretical framework with related and important organizational constructs will add further depth to understanding the construct validity of what constitutes psychological ownership. 
And as indicated in the introductory comments, this study has explicitly focused more on the positive side of psychological ownership, only one potential antecedent (transformational leadership), and a limited set of desirable attitudinal outcomes. Therefore, it should be noted again that prior research has indicated there may be a "dark side" to psychological ownership. For example, research has acknowledged the negative side to a degree with the concept of preventative ownership, where individuals become so territorial and even aggressive about target's of ownership that organizational change becomes very difficult to implement (e.g., Brown et al., 2005; Pierce et al., 2003). Future research should also examine the role of such preventative ownership. This could consider the potentially more destructive forms of ownership and how they impact important processes such as organizational change, which may have only been captured in part by the territoriality scale in this study.

Another limitation may be the comprehensiveness of the dimensions used to represent psychological ownership. Dimensions that prior theoretical contributions have linked directly to feelings of psychological ownership were intentionally incorporated. With this caveat, it should be noted that future theory-building and research may demonstrate a link between psychological ownership and other related concepts such as responsibility or autonomy. In particular, ties to recently emerging positive organizational behavior resources such as psychological capital (Luthans et al., 2007) and psychological well-being (Quick \& Quick, 2004; Wright, 2005; Wright \& Cropanzano, 2004) would be useful avenues for future research to pursue.

Finally, there was the potential for common method bias in the study. The extent to which common method effects influenced the study findings is unknown. However, the purpose of this study was not to test hypotheses, but rather to explore the theoretical and empirical dimensions of a broad perspective of psychological ownership.

\section{Implications and conclusion}

Quinn (1996) has lamented that employees may unfortunately be understood as prostitutes; trading their time for money, with no will, energy or passion for their work. This is in contrast to O'Reilly's (2002, p. 19) observation that "when managers talk about ownership, what they typically want to instill is not financial ownership but psychological ownership - a feeling on the part of the employees that they have a responsibility to make decisions that are in the long term interest of the company." Results here provide beginning support that having employees who feel like owners is beneficial in terms of their work attitudes such as commitment, intentions to stay with the organization, and job satisfaction.

Results also suggest that psychological ownership may be positively affected in organizations through transformational leadership. Human resource practitioners have typically been limited to employee stock ownership plans, stock options, or compensation schemes such as $401 \mathrm{ks}$ (e.g. Wagner et al., 2003) to promote feelings of ownership. However, these techniques appear to have contributed relatively little to the understanding of psychological ownership or to developing psychological ownership in employees (Rousseau, 2003). A broader understanding and perspective of psychological ownership as presented may yield fruitful research in examining the issue of fostering and maintaining employee psychological ownership.

For the future, development processes and applications for psychological ownership need to be given focused attention. Just as the positive resource of psychological capital development has been recently demonstrated (see Luthans, Avey, Avolio, Norman, \& Combs, 2006; Luthans et al., 2007), the identified components of the positive form of psychological ownership (i.e., self-efficacy, accountability, sense of belongingness, and self-identity) may also be developed in carefully designed and executed training interventions. Moreover, based on the relationship that transformational leadership 
seems to have on psychological ownership, the recent work on leadership development in general, and authentic leadership development in particular (e.g., see Avolio \& Luthans, 2006; Gardner, Avolio, Luthans, May, \& Walumbwa, 2005), would seem to have significant practical implications for psychological ownership management and development, and, in turn, performance impact in organizations. In conclusion, these results are intended to provide a platform and stimulation for further discussion and empirical research on the positive resource of psychological ownership and how it can potentially relate to all facets of individual, group, and organizational effectiveness and ultimately competitive advantage.

James B. Avey is an Assistant Professor of Management, Central Washington University. Dr. Avey earned his Ph.D. from the University of Nebraska-Lincoln in 2007. His research on leadership, positive psychological capital and psychological ownership has been published in outlets such as Personnel Psychology, Journal of Organizational Behavior, and Journal of Management.

Bruce J. Avolio is the Marion B. Ingersoll Professor, Foster School of Business, University of Washington. Dr. Avolio has published nine books and over a hundred articles on leadership and related areas. His newest books are Leadership Development in Balance: Made/Born, The High Impact Leader: Moments Matter in Authentic Leadership Development, and Psychological Capital: Developing the Human Competitive Edge, with Fred Luthans and Carolyn Youssef.

Craig D. Crossley is a postdoctoral research associate in the Department of Management at the University of Nebraska-Lincoln. His research interests include leadership, counterproductive workplace behaviors, and decision making. Craig's research has been published in journals such as Journal of Applied Psychology, Human Relations, and Journal of Vocational Behavior.

Fred Luthans is the George Holmes Distinguished Professor of Management, University of Nebraska-Lincoln. Professor Luthans has published several major books and over a hundred and fifty articles on organizational behavior and related areas. A former President of the Academy of Management, his latest research is concerned with positive organizational behavior and psychological capital.

\section{References}

Abrams, D., \& Hogg, M. A. (2004). Meta-theory: Lessons from social identity research. Personality \& Social Psychology Review, 8, 98-106.

Albert, S., Ashforth, B. E., \& Dutton, J. E. (2000). Organizational identity and identification: Charting new waters and building new bridges. Academy of Management Review, 25, 13-17.

Allen, N. J., \& Meyer, J. P. (1990). The measurement and antecedents of affective, continuance and normative commitment to the organization. Journal of Occupational Psychology, 63, 1-18.

Altman, I. (1975). The environment and social behavior: Privacy, personal space, territory, crowding. Monterrey, CA: Brooks/Cole.

Ardrey, R. (1966). The territorial imperative: A personal inquiry into the animal origins of property and nations. New York: Dells.

Ashforth, B. E., \& Mael, F. (1989). Social identity theory and organization. Academy of Management Review, 14, 20-39.

Avolio, B. J., Bass, B., \& Jung, D. (1999). Re-examining the components of transformational and transactional leadership using multi-factor leadership questionnaire. Journal of Occupational and Organizational Psychology, 72, 441-462. 
Avolio, B. J., \& Luthans, F. (2006). The high impact leader: Moments matter in accelerating authentic leadership development. New York: McGraw-Hill.

Bandura, A. (1997). Self-efficacy: The exercise of control. New York: Freeman.

Bass, B. M., \& Riggio, R. (2006). Transformational leadership. Mahwah, NJ: Lawrence Erlbaum.

Belk, R. W. (1988). Possessions and the extended self. Journal of Consumer Research, 15, 139-168.

Blau, P. M. (1964). Exchange and power in social life. New York: Wiley.

Bluedorn, A. (1982). A unified model of turnover from organizations. Human Relations, 35, 135-153.

Brief, A. P., \& Weiss, H. M. (2002). Organizational behavior: Affect in the workplace. Annual Review of Psychology, 53, 279-307.

Brown, G., Lawrence, T. B., \& Robinson, S. L. (2005). Territoriality in organizations. Academy of Management Review, 30, 577-594.

Cameron, K. Dutton, J. \& Quinn R. (Eds.) (2003). Positive organizational scholarship. San Francisco: Berrett- Koehler.

Cram, F., \& Paton, H. (1993). Personal possessions and self identity: The experiences of elderly women in three residential settings. Australian Journal on Aging, 12, 19-24.

Dirks, K. T., Cummings, L. L., \& Pierce, J. L. (1996). Psychological ownership in organizations: Conditions under which individuals promote and resist change. In R. W. Woodman, \& W. A. Pasmore (Eds.), Research in organizational change and development (Vol. 9 pp. 1-23). Greenwich, CT: JAI Press.

Dittmar, H. (1992). The social psychology of material possessions: To have is to be. New York: St. Martin's Press.

Duncan, N. G. (1981). Home ownership and social theory. In J. S. Duncan (Ed.), Housing and identity: Cross- cultural perspectives: (98-134). London: Croom Helm.

Fox, S., \& Spector, P. E. (1999). A model of work frustration-aggression. Journal of Organizational Behavior, 20, $915-931$.

Fredrickson, B. L. (2001). The role of positive emotions in positive psychology: The broaden-and-build theory of positive emotions. American Psychologist, 56, 218-381.

Furby, L. (1991). Understanding the psychology of possession and ownership: A personal memoir and an appraisal of our progress. Journal of Social Behavior and Personality, 6, 457-463.

Gardner, W. L., Avolio, B. J., Luthans, F., May, D. R., \& Walumbwa, F. O. (2005). Can you see the real me? A self- based model of authentic leader and follower development. Leadership Quarterly, 16, 343-372.

Hackman, J. R., \& Oldham, G. R. (1980). Work redesign. Reading, MA.

Higgins, E. T. (1997). Beyond pleasure and pain. American Psychologist, 52, 1280-1300.

Higgins, E. T. (1998). Promotion and prevention: Regulatory focus as a motivational principle. In M. P. Zanna (Ed.), Advances in experimental social psychology, Vol. 30, (1-46). New York: Academic Press.

Hinkin, T. R. (1995). A review of scale development practices in the study of organizations. Journal of Management, 21, 967-988.

Hinkin, T. R. (1998). A brief tutorial on the development of measures for use in questionnaires. Organizational Research Methods, 1, 104-121.

Hobfoll, S. (2002). Social and psychological resources and adaptation. Review of General Psychology, 6, $307-324$.

Judge, T. A., \& Bono, J. E. (2001). Relationship of core self-evaluation traits - self-esteem, generalized self efficacy, locus of control, and emotional stability - with job-satisfaction and performance: A meta-analysis. Journal of Applied Psychology, 86, 80-92.

Judge, T. A., Erez, A., Bono, J. E., \& Thoresen, C. J. (2003). The core self-evaluation scale: Development of a measure. Personnel Psychology, 56, 303-331.

Kark, R., \& Van Dijk, D. (2007). Motivation to lead, motivation to follow: The role of the self regulatory focus in leadership processes. Academy of Management Review, 32, 500-528.

Katz, D., \& Kahn, R. L. (1978). The social psychology of organizations (2nd ed.). New York: Wiley.

Kluger, A. N., Stephan, E., Ganzach, Y., \& Hershkovitz, M. (2004). The effect of regulatory focus on the shape of probability-weighting function: Evidence from a cross-modality matching method. Organizational Behavior and Human Decision Processes, 95, 20-39.

Law, K. S., Wong, C., \& Mobley, W. H. (1998). Toward a taxonomy of multidimensional constructs. Academy of Management Review, 23, 741-755.

Lee, K., \& Allen, N. J. (2002). Organizational citizenship behavior and workplace deviance: The role of affect and cognitions. Journal of Applied Psychology, 87, 131-142. 
Lerner, J. S., \& Tetlock, P. E. (1999). Accounting for the effects of accountability. Psychological Bulletin, 125, 255-275.

Liberman, N., Idson, L. C., Camacho, C. J., \& Higgins, T. E. (1999). Promotion and prevention choices between stability and change. Journal of Personality and Social Psychology, 77, 1135-1145.

Luthans, F. (2002a). The need for and meaning of positive organizational Behavior. Journal of Organizational Behavior, 23, 695-706.

Luthans, F. (2002b). Positive organizational behavior: Developing and managing psychological strengths. Academy of Management Executive, 16, 57-72.

Luthans, F., Avey, J. B., Avolio, B. J., Norman, S. M., \& Combs, G. M. (2006). Psychological capital development: Toward a micro-intervention. Journal of Organizational Behavior, 27, 387-393.

Luthans, F., Youssef, C. M., \& Avolio, B. J. (2007). Psychological capital: Developing the human competitive edge. Oxford, UK: Oxford University Press.

MacKenzie, S. B., Podsakoff, P. M., \& Fetter, R. (1991). Organizational citizenship behavior and objective productivity as determinants of managerial evaluations of salespersons' performance. Organizational Behavior and Human Decision Processes, 50, 123-150.

Mael, F., \& Ashforth, B. E. (1992). Alumni and their alma mater: A partial test of the reformulated model of organizational identification. Journal of Organizational Behavior, 13, 103-123.

Mehta, R., \& Belk, R. (1991). Artifacts, identity and transition: Favorite possessions of Indians and Indian immigrants to the U.S. Journal of Consumer Research, 17, 398-411.

O'Reilly, C. E. (2002). The wrong kind of ownership. Across the Board, Sept/Oct, 19-20.

Parker, S. (1998). Enhancing role-breadth self efficacy: The roles of job enrichment and other organizational interventions. Journal of Applied Psychology, 83, 835-852.

Peterson, C. (2006). A primer in positive psychology. Oxford, UK: Oxford University Press.

Peterson, C., \& Seligman, M. (2004). Character strengths and virtues: A handbook and classification. New York: Oxford University Press.

Pierce, J. L., Kostova, T., \& Dirks, K. T. (2001). Toward a theory of psychological ownership in organizations. Academy of Management Review, 26, 298-310.

Pierce, J. L., Kostova, T., \& Dirks, K. T. (2003). The state of psychological ownership: Integrating and extending a century of research. Review of General Psychology, 7, 84-107.

Pierce, J. L., O’Driscoll, M. P., \& Coghlan, A. M. (2004). Work environment structure and psychological ownership: The mediating effects of control. Journal of Social Psychology, 144, 507-534.

Pierce, J. L., Rubenfeld, S. A., \& Morgan, S. (1991). Employee ownership: A conceptual model of process and effects. Academy of Management Review, 16, 121-144.

Pratt, M. G., \& Dutton, J. E. (1998). Owning up or opting out: The role of identities and ambivalence in issue ownership. In N. M. Ashkanasy, C. E. Härtel, \& W. J. Zerbe (eds.), Emotions in the workplace: Research, theory, and practice (pp. 104-129). Westport, CT: US: Quorum Books/Greenwood Publishing Group, Inc., 2000.

Quick, J. C., \& Quick, J. D. (2004). Health, happy, productive work: A leadership challenge. Organizational Dynamics, 33, 329-337.

Quinn, R. E. (1996). Deep change: Discovering the leader within. San Francisco, CA: Jossey-Bass.

Rousseau, D. M. (2003). Pieces of the action: Ownership and the changing employment relationship. Academy of Management Review, 28, 553-571.

Rousseau, D. M. (1998). Why workers still identify with organizations. Journal of Organizational Behavior, 19, 217-233.

Shamir, B., House, R. J., \& Arthur, M. B. (1993). The motivational effect of charismatic leadership: A self-concept based theory. Organizational Science, 4, 577-594.

Stanton, J. M., Sinar, E. F., Balzer, W. K., \& Smith, P. C. (2002). Issues and strategies for reducing the length of self report scales. Personnel Psychology, 55, 167-194.

Tajfel, H., \& Turner, J. (1986). The social identity theory of intergroup behavior. In S. Worchel, \& W. Austin (Eds.), Psychology of Intergroup Relations (pp. 7-24.). Chicago: Nelson Hall.

Van Dyne, L., \& Pierce, J. L. (2004). Psychological ownership and feelings of possession: Three field studies predicting employee attitudes and organizational citizenship behaviors. Journal of Organizational Behavior, 25, 439-459.

Wagner, S. H., Parker, C. P., \& Christianson, N. D. (2003). Employees that think and act like owners: Effects of ownership beliefs and behaviors on organizational effectiveness. Personnel Psychology, 56, 847- 871. 
White, R. W. (1959). Motivation reconsidered: The concept of competence. Psychological Review, 66, 297-330.

Wright, T. A. (2005). The role of "happiness" in organizational research: Past, present, and future directions. In P. L. Perrewe, \& D. C. Ganster (Eds.), Research in occupational stress and well-being (Vol. 4, pp. 221-264). Amsterdam: JAI Press.

Wright, T. A., \& Cropanzano, R. (2004). The role of psychological well-being in job performance. Organizational Dynamics, 33, 338-351.

\section{Appendix A:}

\section{Sample Items of Psychological Ownership Measure and Item Factor Loadings}

\section{Territoriality}

T1: I feel I need to protect my ideas from being used by others in my organization $(0.62,0.82)$

T2: I feel that people I work with in my organization should not invade my workspace $(0.79,0.80)$

T3: $(0.87,0.89)$

T4: $(0.70,0.75)$

Self-Efficacy

E1: I am confident in my ability to contribute to my organization's success $(0.87,0.96)$

E2: I am confident I can make a positive difference in this organization $(0.96,0.81)$

E3: $(0.78,0.98)$

Accountability

A1: I would challenge anyone in my organization if I thought something was done wrong $(0.62,0.81)$

A2: I would not hesitate to tell my organization if I saw something that was done wrong $(0.73,0.79)$

A3: $(0.98,0.87)$

Sense of Place or Belongingness

PL1: I feel I belong in this organization $(0.96,0.88)$

PL2: I am totally comfortable being in this organization $(0.76,0.91)$

PL3: $(0.84,0.87)$

Self-Identity

I1: I feel this organization's success is my success $(0.84,0.70)$

I2: I feel being a member in this organization helps define who I am $(0.67,0.80)$

I3: $(0.70,0.74)$

The numbers following each item stem are the factor loadings for each item in Study 1 and Study 2.

The full scale for psychological ownership can be obtained from the first author. 